\title{
PRODUCTION POTENTIAL AND COMPETITIVE INDICES OF MUSTARD BASED INTERCROPPING WITH WHEAT UNDER DIFFERENT ROW RATIOS
}

\author{
P.K. Biswas, H. Chakma and T.S.Roy \\ Department of Agronomy \\ Sher-e-Bangla Agricultural University, Sher-e-Bangla Nagar, Dhaka-1207 \\ Corresponding E-mail: parimalbiswas@hotmail.com
}

(Received: 19 February 2020, Accepted: 30 March 2020)

Keywords: Wheat, mustard, intercrop, wheat equivalent yield, BCR

\begin{abstract}
An experiment was conducted at the Agronomy research field, Sher-e-Bangla Agricultural University, Dhaka from November, 2015 to March, 2016 to study the performance of wheat-mustard intercropping as influenced by different row ratios. Ten treatments were included in the study as, $\mathrm{T}_{1}$ (sole wheat), $\mathrm{T}_{2}$ (sole mustard), $\mathrm{T}_{3}$ (wheatmustard in 2:1 rows), $\mathrm{T}_{4}$ (wheat-mustard in 3:1 rows), $\mathrm{T}_{5}$ (wheat-mustard in 4:1 rows), $\mathrm{T}_{6}$ (wheat-mustard in 5:1 rows), $\mathrm{T}_{7}$ (wheat-mustard in 2:2 rows), $\mathrm{T}_{8}$ (wheat-mustard in 3:2 rows), $\mathrm{T}_{9}$ (wheat-mustard in 4:2 rows) and $\mathrm{T}_{10}$ (wheat-mustard in 5:2 rows). The experimental result indicatedthe significant variations of wheat yield by the wheatmustard intercropping system. The highest seed yield of wheat $\left(3.4 \mathrm{t} \mathrm{ha}^{-1}\right)$ was obtained from $\mathrm{T}_{1}$ (sole wheat) that identical with $\mathrm{T}_{4}$ (wheat-mustard in 3:1 rows) and similar with $\mathrm{T}_{9}$ (wheat-mustard in 4:2 rows). Wheat yield gradually decreased with increasing mustard rows. The lowest seed yield $\left(1.87 \mathrm{t} \mathrm{ha}^{-1}\right)$ was obtained from $\mathrm{T}_{7}$ (wheat-mustard in 2:2 rows) which was statistically similar to $\mathrm{T}_{8}$ (wheat-mustard in 3:2 rows). The highest wheat equivalent yield $\left(5.03 \mathrm{tha}^{-1}\right)$ was obtained from $\mathrm{T}_{4}$ (wheat-mustard in 3:1 rows). Treatment $\mathrm{T}_{4}$ (wheat-mustard in 3:1 rows) produced the highest LER (1.45). Economic analysis of the different treatments showed that the highest gross return (Tk. $120250.0 \mathrm{ha}^{-}$ ${ }^{1}$ ), the highest net return (Tk. $61178.0 \mathrm{ha}^{-1}$ ) and BCR (2.04) from $\mathrm{T}_{4}$ (wheat-mustard in 3:1 rows). Therefore, present study suggest that wheat and mustard intercropped in 3:1 rows showed the most compatible in respect of yield advantage and economic gain.
\end{abstract}

\section{Introduction}

The practice of growing two or more crops simultaneously in the same field is called intercropping. It is a common feature in traditional farming of small landholders. It provides farmers with a variety of returns from land and labour, often increases the efficiency with which scarce resources are used and reduces the failure risk of a single crop that is susceptible to environmental and economic fluctuation. Main purpose of intercropping is to produce a greater yield on a given piece of land by making use of resources in the way of maximum efficiency. The need for increased production of oilseed can also be fulfilled through their intercropping with wheat. Besides intercropping of compatible crops use resources very efficiently and provides yield advantage over sole crops. In intercropping farming system, usually one main crop and one or more were used as added crops (Sakaet al., 2007). According to Sharma et al. (1993) mixture of cereals and legumes gave higher yield than their respective sole crops. Similarly Mandalet al. (1991) reported that wheat plus chickpea intercropping gave higher yield of wheat and water-use efficiency than wheat plus rapeseed intercropping. Kerrio and Aslam (1986) suggested that two crops of differing height, canopy and growth habits can be grown simultaneously with least competition. Malik et al. (1998) reported that yield and yield components of wheat were significantly affected by association of chickpea, lentil and rapeseed while Mikhovet al. (1991) stated that wheat yield in pure stand was significantly higher than mix cropping under rainfed conditions. 
Naziret al. (1988) also reported that intercropping of lentil (Lens culinaris), Sarson(Brassica napus) and chickpea (Cicerarietinum) decreased the wheat yield over wheat alone under un-irrigated conditions, however, the losses were compensated by their additional harvest in terms of net income.

Intercropping provides an efficient utilization of environmental resources, decreases the cost of production, provides higher financial stability for farmers, decreases pest damages, inhibits weeds growth more than monocultures, and improves soil fertility through nitrogen increasing to the system and increase yield and quality (Francis et al., 1976; Willey, 1979). It is now clear that the weeds could interfere with crops by increasing competition (for light, water, nutrients and space) and/or allelopathy. Weeds declines crops yields and it lead to higher cost in agricultural productions (Wanjariet al., 2001; Pandya et al., 2005; Singh and Giri, 2001). There is need to develop the best cropping pattern to increase the production of mustard and wheat crop concomitantly. It has been shown that intercropping helps in increasing farm income (Kalra and Gangwar, 1980). Sharma et al. (1986) reported that plant density showed significant difference by intercropping of wheat and mustard comparing to mono culture and found the highest land equivalent ratio (LER) by intercropping wheat and rape in a 1:1 row ratio. Singh and Pal (1994) reported that intercropping of wheat and mustard reduced the seed yield than their pure stands. Whereas, Ayisiet al. (1997) concluded from their experiment on canola-soybean intercropping that seed oil content increased compared with sole cropping. Likewise, Vermaet al. (1997) reported that intercropping of wheat and Indian mustard gave maximum net return, benefit-cost ratio and land equivalent ratio. One of the most advantages of using herbicides is simplified weed control, but the use of herbicides, not only is costly but also selection of herbicide-resistant weed biotypes seriously become an environmental contamination factor now a day. Herbicide use reduction is one of the main target of sustainable, and so several alternatives being investigated, including intercropping. The allelopathic potentiality of Brassica to control weeds in wheat field was also reported (Rahman et al., 2012; Biswas et al., 2013 \& 2014; Biswas et al., 2014). The study was therefore undertaken to compare the performance of intercropping with different row ratios of wheat and mustard and to determine the possibility of increasing monetary advantage with wheat-mustard intercropping.

\section{Materials and Methods}

The experiment was conducted at the Agronomy field of Sher-e-Bangla Agricultural University, Dhaka during the period from November 2015 to June 2016. The farm belongs to the general soil type, Shallow Red Brown Terrace Soils under Tejgaon Series. The land was above flood level and sufficient sunshine was available during the experimental period. The seeds of wheat variety BARI gom-30 and mustard variety BARI Sarisha-16 were collected from Bangladesh Agricultural Research Institute (BARI), Joydebpur, Gazipur. The experimental plot was ploughed and cross ploughed with the help of disc plough and harrow. The land was finally leveled with leveler to ensure uniform application of water. The lay-out of the experiment was done by maintaining $5 \mathrm{~m} \times 2 \mathrm{~m}$ plot having $0.5 \mathrm{~m}$ gap between two main plot as well as sub-plot; $1.0 \mathrm{~m}$ between two replications. The whole plot was fertilized with the chemical fertilizers @100-80-30-20 kgha ${ }^{-1}$ of N, $\mathrm{P}_{2} \mathrm{O}_{5}, \mathrm{~K}_{2} \mathrm{O}$ and $\mathrm{S}$ from their sources of urea, TSP, $\mathrm{MoP}$ and Gypsum, respectively. The whole amount of all fertilizers except urea was applied as a basal dose during final land preparation. The urea fertilizer was applied as two equal installments; $50 \%$ as basal dose and rest before flowering. The wheat and mustard seeds were sown on November 24, 2015. The spacing was maintained as per treatments. The experiment was laid out in a randomized complete block design with three replications. The treatments were: i) Sole wheat $\left(\mathrm{T}_{1}\right)$, ii) Sole mustard $\left(\mathrm{T}_{2}\right)$, iii) Wheat-mustard in 2:1 row ratios $\left(\mathrm{T}_{3}\right)$, iv) Wheat-mustard in 3:1 row ratios $\left(\mathrm{T}_{4}\right)$, v) Wheat-mustard in 4:1 row ratios $\left(\mathrm{T}_{5}\right)$, vi) Wheat-mustard in 5:1 row ratios $\left(\mathrm{T}_{6}\right)$, vii) Wheat-mustard in 2:2 row ratios $\left(\mathrm{T}_{7}\right)$, viii) Wheat-mustard in 3:2 row ratios $\left(\mathrm{T}_{8}\right)$, ix) Wheat-mustard in 4:2 row ratios $\left(\mathrm{T}_{9}\right)$ and $\mathrm{x}$ ) Wheatmustard in 5:2 row ratios $\left(\mathrm{T}_{10}\right)$. Water was ensured to the field in such a way that there should not have any scarcity of water that affects the experiment. Two hand weedings were done for all the treatments. The field was infested by different insects and diseases those controlled by applying appropriate ways in time. The mustard was harvested on 100 days after sowing and wheat after 120 days of sowing. Ten 
plants per plot for both wheat and mustard were randomly selected for collecting yield contributing and other relevant data like plant height, no. of spikesplant ${ }^{-1}$, no. of grains spike ${ }^{-1}$ and 1000 grain weight for wheat and plant height, no. of siliquaeplant ${ }^{-1}$, no. of seedssiliqua ${ }^{-1}$ and 1000 seed weight for mustard. The seed yield of both the crops and wheat equivalent yield, land equivalent ratio, gross return, net return and benefit cost ratio were also recorded. Statistical analyses were done by using the CropStat computer package and the mean differences among the treatments were compared by least significant difference test at $5 \%$ level of significance following Gomez and Gomez (1984).

\section{Wheat}

\section{Results and Discussion}

\section{Plant height}

The plant height of wheat was significantly influenced by different row ratios of wheat and mustard intercrop with the advancement of plant age. At 25 DAS, there was less differences observed on plant height but it showed increasing trend with advancement of growth up to 75 DAS and then slightly increased up to harvest. The tallest plant was obtained from $\mathrm{T}_{4}(95.03 \mathrm{~cm})$ and the shortest plant from $\mathrm{T}_{9}(72.67 \mathrm{~cm})$ that similar to $\mathrm{T}_{7}(75.2 \mathrm{~cm})$ at harvest (Figure1).

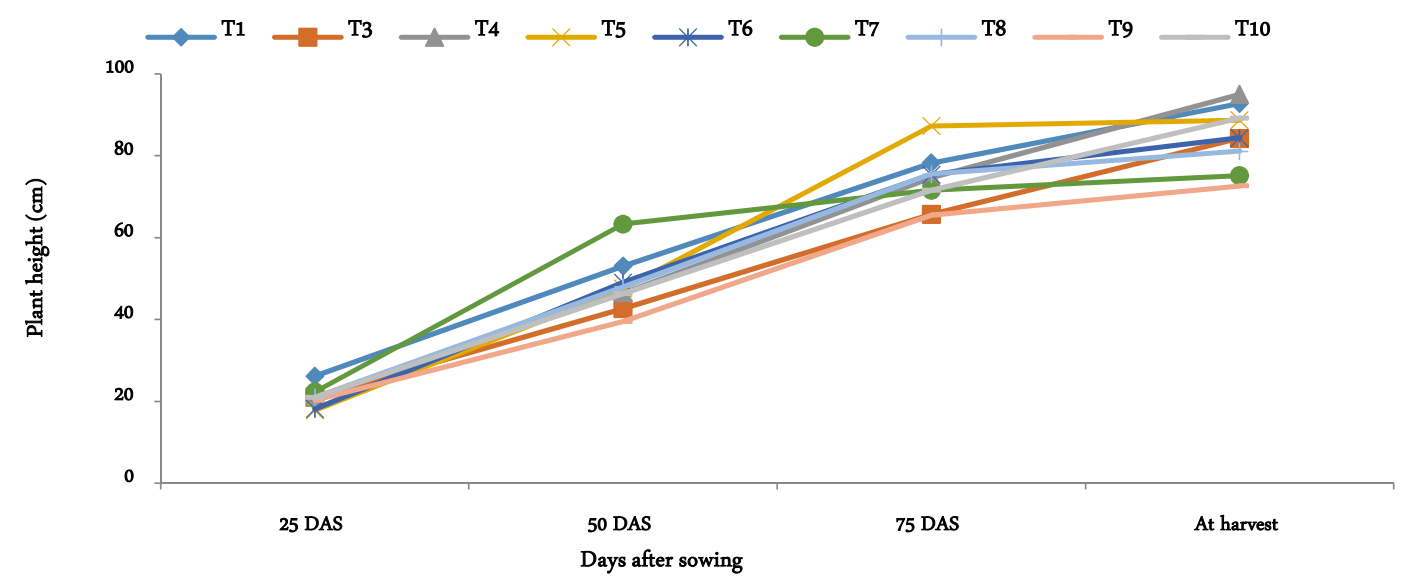

$\mathrm{T}_{1}$ : Sole wheat

$\mathrm{T}_{3}$ : Wheat-mustard in $2: 1$ rows

$\mathrm{T}_{4}$ : Wheat-mustard in 3:1 rows
$\mathrm{T}_{5}:$ Wheat-mustard in $4: 1$ rows

$\mathrm{T}_{6}$ : Wheat-mustard in 5:1 rows

$\mathrm{T}_{7}$ : Wheat-mustard in $2: 2$ rows
$\mathrm{T}_{8}$ : Wheat-mustard in 3:2 rows

$\mathrm{T}_{9}$ : Wheat-mustard in $4: 2$ rows

$\mathrm{T}_{10}$ : Wheat-mustard in 5:2 rows

Fig.1. Effect of wheat-mustard intercropping on plant height of wheat $\left[\operatorname{LSD}_{(0.05)}=5.91,4.47,8.28\right.$ and 3.71 at $25,50,75$ DAS and atharvest, respectively].

\section{No. of spikesplant ${ }^{-1}$}

In intercropping with different row ratios, spike number of wheat was significantly affected (Table 1) and the highest number of spikesplant ${ }^{-1}(5.73)$ was obtained from $\mathrm{T}_{4}$ (three rows wheat and one row mustard) that followed by sole wheat (4.63) and $\mathrm{T}_{9}(4.93)$. The lowest number of spikesplant ${ }^{-1}(2.27)$ was found from $\mathrm{T}_{6}$ (five rows wheat and one row mustard). This result was dissimilar to Singh et al.(1995) who reported that the number of shoot or spike bearing tiller of wheat $\mathrm{m}^{-1}$ row length was the highest under pure stand and it decreasedsignificantly when the wheat was grown in any combination with Indian mustard.Mandalet al.(1991) also reported that the number of ear-bearing tillers in wheat was highest when grown alone.

Table 1. Effect of wheat and mustard intercropping with different row ratios on no. ofspikesplant ${ }^{-1}$, 
no. of grainsspike ${ }^{-1}$, wt. of 1000 grains and grain yield of wheat

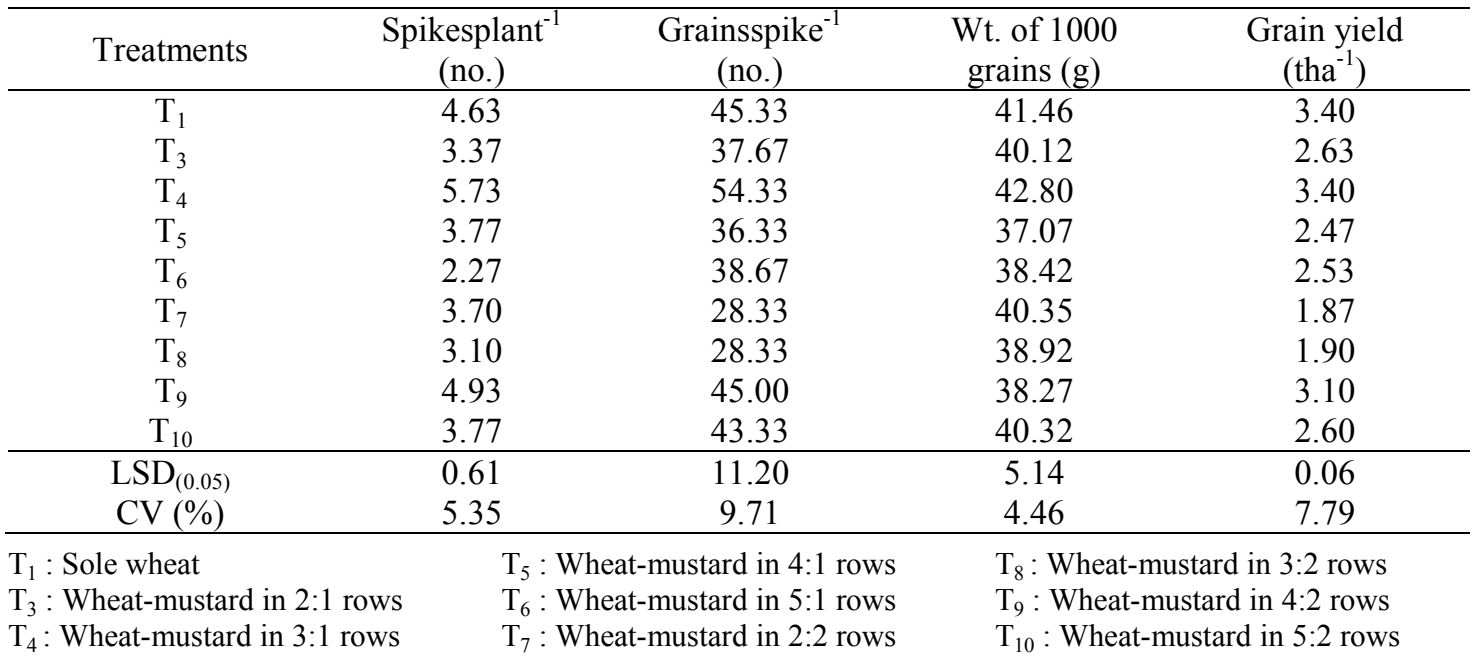

\section{Number of grainsspike $e^{-1}$}

The no. of grainsspike ${ }^{-1}$ showed significant differences on different row ratios of wheat-mustard intercropping system. Treatment $\mathrm{T}_{4}$ (three rows of wheat and one row of mustard) resulted the highest no. of grainsspike ${ }^{-1}$ (54.33). The lowest no. of grainsspike ${ }^{-1}$ (28.33) resulted in $\mathrm{T}_{7}$ (two rows of wheat with two rows mustard) and $\mathrm{T}_{8}$ (three rows wheat with two rows mustard) (Table 1).

\section{Thousand-grain weight}

Treatment $\mathrm{T}_{4}$ (three rows wheat and one row mustard) resulted the highest thousand-grain weight (42.8 g) that similar to other treatments except $T_{5}$ (four rows wheat with one row mustard) which showed the lowest thousand-grain weight $(37.07 \mathrm{~g})$ that also similar to other combinations except $\mathrm{T}_{4}$ (Table 1$)$.

\section{Grain yield}

There was significant difference observed on grain yield of wheat for different row ratios combinations. The highest grain yield $\left(3.4\right.$ tha $\left.^{-1}\right)$ was obtained from sole wheat and $\mathrm{T}_{4}$ (three rows of wheat and one row mustard). The lowest grain yield $\left(1.87 \mathrm{t} \mathrm{ha}^{-1}\right)$ was obtained from $\mathrm{T}_{7}$ (two rows wheat with two rows mustard) that similar to $\mathrm{T}_{8}\left(1.90 \mathrm{t} \mathrm{ha}^{-1}\right)$ and $\mathrm{T} 5\left(2.47 \mathrm{t} \mathrm{ha}^{-1}\right)$. It was observed that grain yield of wheat decreased with increasing mustard population (Table 1).

\section{Mustard}

\section{Plant height}

Significant differences were observed on plant height in mustard when intercropped with wheat (Figure 2). At $25 \mathrm{DAS}$, the highest plant height $(21.52 \mathrm{~cm})$ was found in $T_{3}$ (two row wheat with one row mustard) and the lowest $\left(11.31 \mathrm{~cm}\right.$ ) in $\mathrm{T}_{9}$ (four rows wheat with two rows mustard). At 50 DAS, the highest plant height $\left(109.42 \mathrm{~cm}\right.$ ) was obtained by $\mathrm{T}_{7}$ (two rows wheat with two rows mustard) and the lowest $(75.76 \mathrm{~cm})$ at $\mathrm{T}_{5}$ (four rows wheat with one row mustard). At $75 \mathrm{DAS}, \mathrm{T}_{4}$ (three rows wheat and one row mustard) resulted the highest plant height $(152.33 \mathrm{~cm})$ and the lowest $(136.1$ and $134.7 \mathrm{~cm})$ was found in $T_{5}$ (four rows wheat with one row mustard) and $T_{3}$ (two rows wheat with one row mustard), respectively. At harvest maximum plant height $(170.60 \mathrm{~cm})$ was recorded by $\mathrm{T}_{2}$ (sole mustard) and minimum $(143.67 \mathrm{~cm})$ by $\mathrm{T}_{6}$ (five rows wheat with one row mustard). 


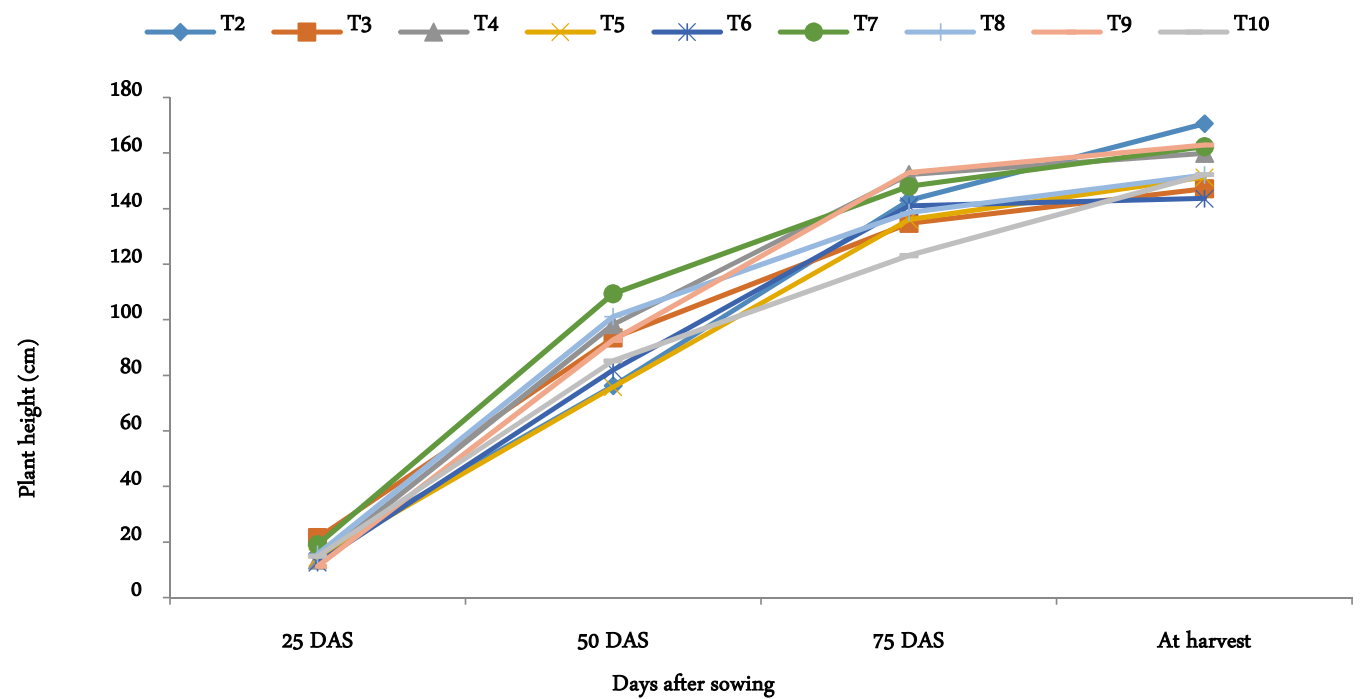

$\mathrm{T}_{2}:$ Sole mustard

$\mathrm{T}_{3}$ : Wheat-mustard in $2: 1$ rows

$\mathrm{T}_{4}$ : Wheat-mustard in $3: 1$ rows
$\mathrm{T}_{5}$ : Wheat-mustard in 4:1 rows

$\mathrm{T}_{6}$ : Wheat-mustard in $5: 1$ rows

$\mathrm{T}_{7}$ : Wheat-mustard in $2: 2$ rows
$\mathrm{T}_{8}$ : Wheat-mustard in 3:2 rows

$\mathrm{T}_{9}$ : Wheat-mustard in $4: 2$ rows

$\mathrm{T}_{10}$ : Wheat-mustard in 5:2 rows

Fig. 2.Effect of wheat-mustard intercropping on plant height of mustard

$\left[\operatorname{LSD}_{(0.05)}=1.60,15.15,10.99\right.$ and 17.5 at $25,50,75 \mathrm{DAS}$ and at harvest,respectively $]$.

\section{Number of siliquaeplant ${ }^{-1}$}

Intercropping wheat with mustard showed significant variation on siliquae plant ${ }^{-1}$ of mustard (Table 2). The highest number of siliquaeplant ${ }^{-1}$ (186.33) was recorded from sole mustard and minimum (56.67) given by the treatment $\mathrm{T}_{6}$ (five rows of wheat with one row mustard).

Table 2. Effect of wheat-mustard intercropping on no. of siliquaeplant ${ }^{-1}$, no. ofseedssiliqua ${ }^{-1}, 1000$ seed weight and seed yield of mustard

\begin{tabular}{ccccc}
\hline Treatments & $\begin{array}{c}\text { Siliquaeplant } \\
\text { (no.) }\end{array}$ & $\begin{array}{c}\text { Seeds siliqua }^{-1} \\
\text { (no.) }\end{array}$ & $\begin{array}{c}\text { Wt. of 1000 } \\
\text { seeds }(\mathrm{g})\end{array}$ & $\begin{array}{c}\text { Seed yield } \\
\text { (tha }^{-1} \text { ) }\end{array}$ \\
\hline $\mathrm{T}_{2}$ & 186.33 & 15.00 & 2.58 & 1.02 \\
$\mathrm{~T}_{3}$ & 94.33 & 7.67 & 2.21 & 0.33 \\
$\mathrm{~T}_{4}$ & 123.33 & 10.00 & 2.26 & 0.46 \\
$\mathrm{~T}_{5}$ & 83.00 & 7.67 & 2.13 & 0.18 \\
$\mathrm{~T}_{6}$ & 56.67 & 6.67 & 2.22 & 0.13 \\
$\mathrm{~T}_{7}$ & 126.00 & 9.67 & 2.18 & 0.29 \\
$\mathrm{~T}_{8}$ & 119.67 & 8.33 & 2.33 & 0.32 \\
$\mathrm{~T}_{9}$ & 127.33 & 10.00 & 2.02 & 0.31 \\
$\mathrm{~T}_{10}$ & 116.67 & 7.33 & 2.26 & 0.24 \\
\hline LSD & 34.31 & 4.85 & NS & 0.15 \\
CV (\%) & 10.29 & 18.25 & 12.05 & 13.82 \\
\hline $\mathrm{T}_{2}:$ Sole mustard & & $\mathrm{T}_{5}$ : Wheat-mustard in $4: 1$ rows & $\mathrm{T}_{8}$ : Wheat-mustard in $3: 2$ rows \\
$\mathrm{T}_{3}:$ Wheat-mustard in $2: 1$ rows & $\mathrm{T}_{6}$ : Wheat-mustard in $5: 1$ rows & $\mathrm{T}_{9}$ : Wheat-mustard in $4: 2$ rows \\
$\mathrm{T}_{4}:$ Wheat-mustard in $3: 1$ rows & $\mathrm{T}_{7}$ : Wheat-mustard in $2: 2$ rows & $\mathrm{T}_{10}$ : Wheat-mustard in $5: 2$ rows
\end{tabular}


Treatment $\mathrm{T}_{2}$ (sole mustard) resulted the highest $(15.00)$ no. of seeds siliqua ${ }^{-1}$ that significantly varied with all other treatments and the lowest (6.67) number was recorded from $\mathrm{T}_{6}$ (five rows wheat with one row mustard) that similar to other treatments except $\mathrm{T}_{2}$ (Table 2 ).

\section{Wt. of 1000-seeds}

There was no significant variation in thousand-seed weight of mustard observed when intercropped with wheat (Table 2). Sharma et al. (1986) conducted an experiment of intercropping mustard with wheat during winter season on a sandy clay loam soil at Pantnagar and observed that 1000 -seed weight of mustard remain unaffected due to intercropping.

\section{Seed yield}

Seed yield of mustard resulted significant differences when intercropped with wheat. Sole mustard showed the highest seed yield $\left(1.02 \mathrm{t} \mathrm{ha}^{-1}\right)$ might be due to larger area and population while the treatment $\mathrm{T}_{6}$ (five rows wheat with one row of mustard) resulted the lowest $\left(0.13 \mathrm{t} \mathrm{ha}^{-1}\right)$ seed yield (Table 2).

\section{Wheat equivalent yield}

The wheat equivalent yield was significantly affected by wheat-mustard intercropping. (Figure 3 ). The highest wheat equivalent yield $\left(5.03 \mathrm{tha}^{-1}\right)$ was obtained from $\mathrm{T}_{4}$ (three rows wheat and one row mustard) that similar to $T_{9}$ (four rows wheat with two rows mustard). The lowest wheat equivalent yield $\left(2.89 \mathrm{tha}^{-1}\right)$ of observed in $\mathrm{T}_{7}$ that similar to $\mathrm{T}_{8}, \mathrm{~T}_{6}$ and $\mathrm{T}_{5}$.

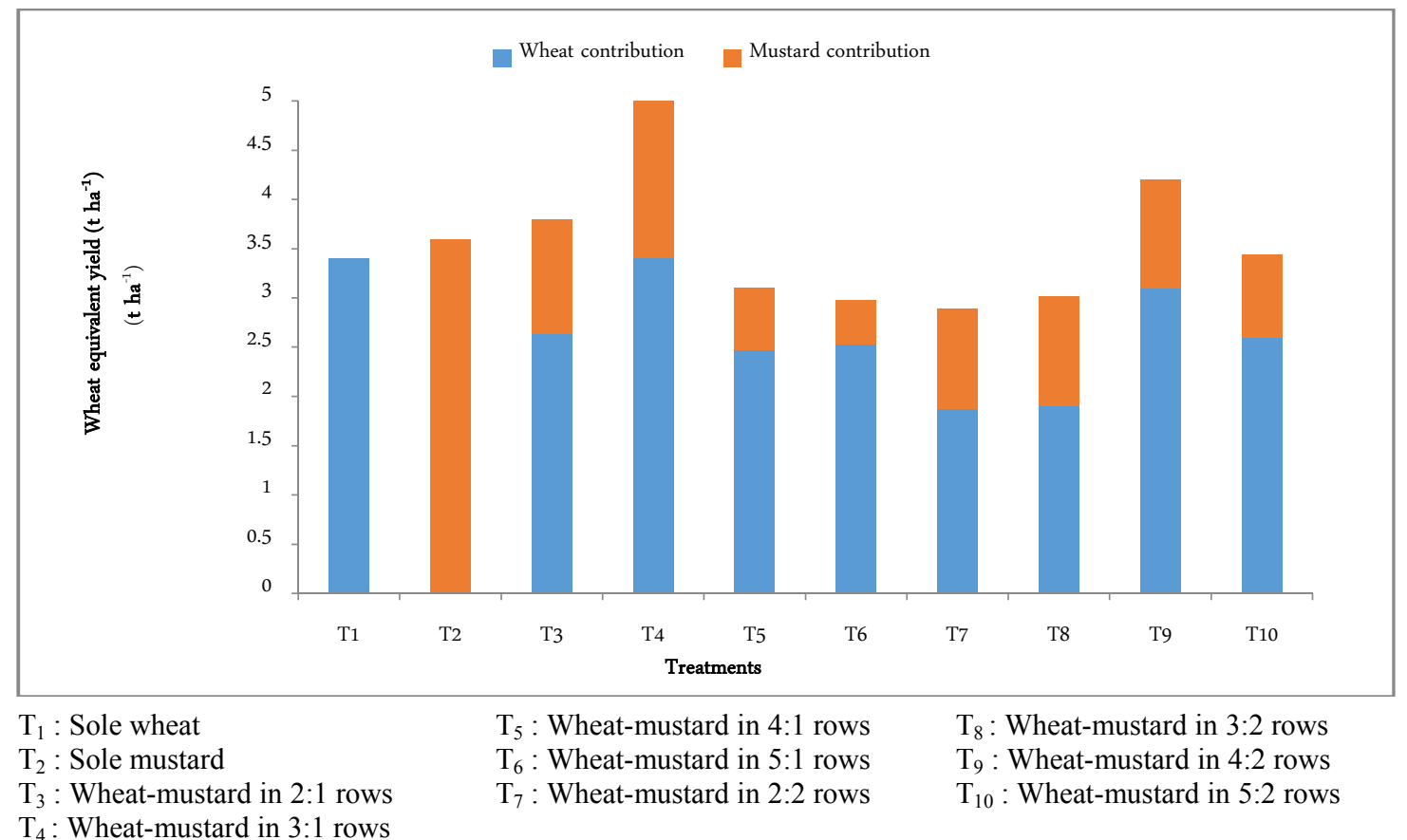

Fig.3. Effect of wheat and mustard intercropping on wheat equivalent yield $\left[\operatorname{LSD}_{(0.05)}=0.85\right]$. 


\section{Land equivalent ratio (LER)}

In wheat and mustard intercropped, significant differences was found in land equivalent ratio for different treatments (Table 3). Treatment $\mathrm{T}_{4}$ (three rows wheat with one row mustard) showed the highest (1.45) land equivalent ratio. Cultivable land in the whole world is decreasing day by day and sole cropping needs more land than intercropping system. So, intercropped can served in an advantage by proper land utilization. Vermaet al. (1997) reported higher land equivalent ratio in case of intercropping of wheat and Indian mustard.

\section{Gross return}

The gross return of wheat and mustard intercropping under different row ratios showedvariations among the treatments (Table 3). It was found that the intercropping treatments always gave better gross return than the sole crops. The maximum gross return (Tk. $120250.0 \mathrm{ha}^{-1}$ ) was obtained from the treatment $\mathrm{T}_{4}$ (three rows wheat followed with one row mustard) and the minimum gross return (Tk. $71787.5 \mathrm{ha}^{-1}$ ) from $\mathrm{T}_{6}$ (five rows wheat and two rows mustard).

Table 3. Effect of wheat-mustard intercropping on LER and other economic productivity

\begin{tabular}{ccccc}
\hline Treatments & LER & $\begin{array}{c}\text { Gross return } \\
\left(\mathrm{Tk}^{-1} \mathrm{ha}^{-1}\right)\end{array}$ & $\begin{array}{c}\text { Net return } \\
\left(\mathrm{Tk}^{-1} \mathrm{ha}^{-1}\right.\end{array}$ & BCR \\
\hline $\mathrm{T}_{1}$ & 1.00 & 79887.5 & 29395.5 & 1.58 \\
$\mathrm{~T}_{2}$ & 1.00 & 75017.6 & 19657.1 & 1.35 \\
$\mathrm{~T}_{3}$ & 1.09 & 95225.0 & 36153.0 & 1.61 \\
$\mathrm{~T}_{4}$ & 1.45 & 120250.0 & 61178.0 & 2.04 \\
$\mathrm{~T}_{5}$ & 0.90 & 77187.5 & 18115.5 & 1.31 \\
$\mathrm{~T}_{6}$ & 0.87 & 71787.5 & 12715.5 & 1.22 \\
$\mathrm{~T}_{7}$ & 0.83 & 76062.5 & 16990.5 & 1.29 \\
$\mathrm{~T}_{8}$ & 0.87 & 77412.5 & 18340.5 & 1.31 \\
$\mathrm{~T}_{9}$ & 1.22 & 102450.0 & 43378.0 & 1.73 \\
$\mathrm{~T}_{10}$ & 1.00 & 84400.0 & 25328.0 & 1.43 \\
\hline
\end{tabular}

$\mathrm{T}_{1}$ : Sole wheat

$\mathrm{T}_{2}$ : Sole mustard

$\mathrm{T}_{3}:$ Wheat-mustard in $2: 1$ rows

$\mathrm{T}_{4}$ : Wheat-mustard in $3: 1$ rows
$\mathrm{T}_{5}:$ Wheat-mustard in $4: 1$ rows

$\mathrm{T}_{6}$ : Wheat-mustard in $5: 2$ row

$\mathrm{T}_{7}$ : Wheat-mustard in 2:2 row
$\mathrm{T}_{8}$ : Wheat-mustard in $3: 2$ rows

$\mathrm{T}_{9}$ : Wheat-mustard in $4: 2$ rows

$\mathrm{T}_{10}$ : Wheat-mustard in 5:2 rows

\section{Net return}

Net return over variable cost was found encouraging in the intercropping treatments with proper row ratios. Out of different intercropped treatments the maximum net return (Tk. $61178.0 \mathrm{ha}^{-1}$ ) was found in $\mathrm{T}_{4}$ (three rows wheat intercropped with one row mustard). It was also noted that intercrop always did not give the maximum net return if it was not planted by following proper row ratios (Table 3 ).

\section{Benefit cost ratio}

The treatment $\mathrm{T}_{4}$ (three rows wheat intercropped with one row mustard) gave the highest benefit-cost ratio (2.04) that followed by $\mathrm{T}_{9}$ (four rows wheat intercropped with two rows mustard), $\mathrm{T}_{3}$ (two rows wheat intercropped with one row mustard). The lowest benefit-cost ratio (1.22) was obtained from the $\mathrm{T}_{6}$ (five rows wheat with one row mustard) which also gave the lowest net return (Table 3 ). 


\section{Conclusion}

From the findings of the present experiment, it may be concluded that intercropping of wheat and mustard with three rows of wheat and one row of mustard was the most compatible and this combination gave the higher wheat equivalent yield $\left(5.03\right.$ tha $\left.^{-1}\right)$, LER (1.45), net return (Tk. 61178.0 $\mathrm{ha}^{-1}$ ) and BCR (2.04) over normal planting of wheat.

\section{Acknowledgement}

The author acknowledge the Ministry of Science and Technology, Govt. of the People's Republic of Bangladesh for providing him fund under Special Allocation Program to conduct the study.

\section{References}

Ayisi, K.K., D.H. Putnam, G.P. Vance, M.P. Russelle and D.L. Allan. 1997. Strip intercropping and nitrogen effects on seed, oil and protein yields of Canola and Soybean. Agron. J. 81: 23-29.

Biswas, P.K., R. Chakma, M.F. Karim and I.J. Irin. 2013\& 2014. Efficacy of Brassica to control weeds in wheat.Bangladesh J. Weed Sci.4\&5: 1-6.

Biswas,P.K., M.M. Morshed, M.J. Ullah and I.J. Irin. 2014.Allelopathic effect of Brassica on weed control and yield of wheat.Bangladesh Agron. J.17(1): 73-80.

Francis, C.A., C.A. Flor and S.R. Temple. 1976. Adapting varieties for intercropping systems in the tropics. In: Papendick R.I., P.A. Sanches and G.B. Triplett. (eds). Multiple cropping. Special publication number 27. pp.235-253. Madison. American Society of Agronomy.

Gomez, K.A. and A.A. Gomez. 1984. Statistical procedure for agricultural research. International Rice Research Institute. John Wiley and Sons, New York, pp.139-240.

Kalra, G.S. and B. Gangwar. 1980. Economics of intercropping of different legumes with maize at different levels of $\mathrm{N}$ under rainfed conditions. Indian J. Agron. 25: 181-185.

Keerio, H.K. and M. Aslam. 1986. Intercropping in maize crop. Maize production manual, PARC, Islamabad.

Malik, M.A., M.A.Hayat, S. Ahamad and I. Haq. 1998. Intercropping of lentil, gram and rapeseed in wheat under rainfed conditions.Sarhad J. Agric.14(5): 417-421.

Mandal, B.K., S. Dasgupta, and P.K. Roy. 1991. Effect of intercropping on yield components of wheat, chickpea and mustard under different moisture regimes. Field Crop Absts. 39(10): 7025.

Mikhov, M., N. Nankov and I. Dimitrov. 1991. Investigations of growing lentil sown in a mixture with wheat. Rasteriv, dni-Nauki. 28(7-10): 23-29.

Nazir, M.S., H.U.R. Khan, G. Ali and R. Ahmad. 1988. Inter/Relay cropping in wheat planted in multi-row strips at uniform plant population. Pakistan J. Agric. Res.9(3): 305-309.

Pandya, N., G.S. Chouhan and V. Nepalia. 2005. Effect of varieties, crop geometries and weed management on nutrient uptake by soybean (Glycine max) and associated weeds. Indian J. Agron. 50(3): 218220.

Rahman, A., P.K., Biswas, M.S.A. Sarder, M. Hasanuzzaman and M. Malek. 2012. Allelopathic effect of Brassica biomass on weed control and growth of wheat. Bangladesh J. Weed Sci. 3(1 \& 2): 5-10.

Saka, J.O., O.N. Adeniyan, S.R. Akande and M.O. Balogun. 2007. An economic evaluation of intercropping African yam bean, Kenaf and maize in the rain forest zone of Nigeria. Middle East J. Sci. Res. 2: 18.

Sharma, R.K., K.D. Koranne, J.K. Joseph, P. Singh, V. Prakash, R.K. Mitlal, P. Singh and V. Prakash. 1993. VL Massor 4: a new lentil variety for the hills of Uttar Pradesh. Ind. Fmg.42(10): 19-20. 
Sharma, K.C., Y. Sing, P.C. Gupta, S.K. Tripathy, A.K. Bhardwaj and S.P. Singh. 1986. Plant population and spatial arrangement in wheat-mustard intercropping. Indian J. Agron. 31: 154-157.

Singh, S.S., M.D. Ehsanullah, A.K. Singh and B.K. Singh. 1995. Spatial arrangement in wheat (Triticumaestivum) - Indian mustard (Brassica juncea) intercropping. Indian J. Agron.40: 91-93.

Singh, V.B. and G. Giri. 2001. Influence of intercropping and weed-control measures on suppression of weeds and productivity of spring season sunflower (Helianthus annuus) and groundnut (Arachishypogaea). Indian J. Agron. 46(3): 440-444.

Singh, O. and M. Pal. 1994. Performance of wheat + mustard intercropping system in limited irrigation conditions. Ann. Agric. Res. 15: 255-259.

Verma, U.N., S.K. Pal, M.K. Singh and R. Thakur. 1997. Productivity, energetics and competition function of wheat (TriticumaestivumL.) plus Indian mustard (Brassica junceaL.) intercropping under varying fertilizer level. Indian J. Agron. 42: 201-4.

Wanjari, R.H., N.T. Yaduraju and N. Ahujak. 2001. Nutrient uptake by sunflower (Helianthus annuus) and associated weeds during rainy season. Indian J. Agron. 46(3): 541-546.

Willey, R.W. 1979. Intercropping: its importance and research needs. Part II. Agronomy and research approaches. Field Crops Res. 32: 1-10. 